\title{
Breeding potential of lablab [Lablab purpureus (L.) Sweet]: a review on characterization and bruchid studies towards improved production and utilization in Africa
}

\author{
Fanuel K. Letting (D) Pavithravani B. Venkataramana • Patrick A. Ndakidemi
}

Received: 12 February 2021 / Accepted: 14 September 2021 / Published online: 22 September 2021

(C) The Author(s), under exclusive licence to Springer Nature B.V. 2021

\begin{abstract}
Lablab (Lablab purpureus) [Lablab purpureus (L.) Sweet] is termed a lost, underutilized and neglected crop in Africa. Despite the multipurpose use, production, consumption and research are still limited. Wide genetic diversity of lablab germplasm exists in Africa. Diversity studies provide significant information for subsequent research programs and improvement. The advent of genotyping and sequencing technologies has enabled the identification of unique and agronomically important traits. Application of next-generation sequencing on lablab as a pioneer orphan crop is currently underway. This has enabled description of the whole genome, generation of reference genome and resequencing that provide information on variation within the entire genome. Information from these technological advances helps in identifying potential traits for biotic and abiotic stress for further breeding programs. Storage pests specifically bruchids (Callosobruchus spp.), are
\end{abstract}

F. K. Letting $(\bowtie) \cdot$ P. B. Venkataramana .

P. A. Ndakidemi

Department of Sustainable Agriculture, Biodiversity and Ecosystems Management, School of Life Science and Bio-Engineering, The Nelson Mandela African Institution of Science and Technology, Arusha, Tanzania e-mail: lettingf@yahoo.com

F. K. Letting

Department of Seed, Crop and Horticultural Sciences, School of Agriculture and Biotechnology, University of Eldoret, Eldoret, Kenya considered a major obstacle in lablab production. Screening of available genotypes for bruchid resistance and studies on the physical and biochemical factors that confer resistance in lablab is required. Applying advanced technologies provides precise and reliable identification of the novel markers responsible for bruchid resistance allowing for introgression of important genes to breeding programs. This review provides a detailed analysis on the characterization of lablab and the information on bruchid resistance vital for breeding farmer-preferred varieties that possess agronomically beneficial traits. Concerted efforts and research on this neglected crop will enhance its production, utilization and consumption.

Keywords Lablab purpureus - Characterization . Bruchids · Biochemical - Mode of resistance · Breeding

\section{Introduction}

Lablab [Lablab purpureus (L.) Sweet] has been termed as a 'lost, underutilized and neglected orphan crop'(Maass et al. 2010) owing to limited research programs and development concerns. Lablab contributes to tackling food insecurity, nutrient deficiencies, diversification of diets, generation of income, health benefits, soil conservation and climate-smart 
crop (Joshi et al. 2020). Production patterns of lablab have been on a decline due to genetic, agronomic, eroded cultural factors, reduced research focus, economic, market, less awareness of the nutritional value, lack of improved varieties, poor management practices and improvement, as well as the variation in the climate patterns (Bhatt et al. 2019). Competition from the improved legumes whose yield and production patterns are well known has brought about this shift by the producers and the end-user. The waning existence of lablab contributes to a narrow genetic base and decline in important traits considered vital for crop existence and adaptability to various environmental conditions.

Lablab is a multipurpose crop. Several plant parts can be consumed as food i.e. seeds, immature grains, green pods, leaves, biscuits (Davari et al. 2018; Habib et al. 2017; Kilonzi et al. 2017; Rana et al. 2021), animal feed (Murphy et al. 1999), to improve soil fertility (Gebreyowhens 2017; Qamar et al. 2014; Sitienei et al. 2017) and in the form of green manure (Okumu et al. 2018). The latest research findings report the effectiveness of lablab bean extracts being able to impede infections of viral diseases such as influenza and SARS-CoV-2 which has been described as a world pandemic (Liu et al. 2020). This demonstrates the necessity of improving its production and utilization.

Lablab production has been hampered by biotic factors resulting in low production and consumption. Insects pests such as legume pod borer (Helicoverpa armigera Hubner and Maruca vitrata Fabricius) (Boit et al. 2018; Liao et al. 2000; Popoola et al. 2019; Srinivasan 2014), pod boring caterpillars, stem borer (Satyagopal et al. 2014), stink bugs (Coptosoma cribraria Fabricius) (Chawe et al. 2019; Forsythe 2019; Grotelüschen 2014; Mondal et al. 2017; Njarui et al. 2004), parasitic plant such as Anoplocnemis curvipes Fabricius (Watson et al. 2018), Podagrica uniforma (Jac.), Ootheca mutabilis (Sahlb), Nematocerus acerbus (Faust) aphids (Aphis sp.) (Chawe et al. 2019; Srinivasan 2014) pose a major threat during lablab production. During storage, the most important storage pest in Lablab is bruchids (Callosobruchus $s p$.) as reported by (Chawe et al. 2019), resulting in a total loss of up to $90 \%$ of the stored legume grain (Ebinu et al. 2016). Due to a lack of research on the best control method for bruchids attack on lablab, farmer adoption of lablab production has decreased.
Studies on bruchid resistance are necessary to understand the mode of resistance and to be able to breed varieties with the desired traits for farmers.

Current research on lablab has primarily focused on animal feed (Ewansiha et al. 2017) and soil conservation (Whitbread et al. 2011) resulting in genetic erosion and a reduced gene pool in Africa, despite the crop's importance for food and nutritional security (Minde et al. 2020). During the 1930s, studies on land use management in Tanzania's northern region reported the cultivation and production of lablab. However, the acreage under production was reduced to a negligible size by 2000 (Ngailo et al. 2001). Lablab bean germplasm is widely distributed throughout the country, and there is a need to study and document the existence and variation of these germplasms. Germplasm collection, evaluation, characterization, conservation and management are critical steps in lablab crop improvement.

Characterization generates important knowledge on genetic diversity and relationships between populations in a given germplasm resource required for breeding programs. Characterization can be classified based on phenotypic traits (morphological), variation of isoenzymes (biochemical) and deoxyribonucleic acid (DNA) variation (molecular). Morphological and biochemical characterization is limited by the environment and the plant growth and development (Kordrostami et al. 2015). Molecular characterization relies on DNA found abundantly in the genome is more robust and reliable, and is not influenced by the environment or plant growth. Studies on morphological and molecular characterization of lablab have been done to distinguish the relationship and compare evolution paths of genetic resources. However, limited research on biochemical characterization has been documented.

Information on phenotypic and genotypic characters is used to develop a core collection which represents the entire collection with maximum genetic variation and least repetitiveness of the population (Brown 1989b). Germplasm identification and genetic diversity studies are core in crop improvement towards developing improved varieties with farmers' preferred traits such as high yielding, nutritious, marketable value, and ability to withstand abiotic and biotic stresses. Lablab production is constrained by pests and diseases, bruchids (Callosobruchus spp.). Understanding the existing knowledge on bruchid 
resistance management, mechanism and gene action is thus critical for providing a roadmap for plant breeders and geneticists involved in crop improvement.

The previous review on lablab described its status as an underutilized crop (Maass et al. 2010; Naeem et al. 2020) genetic resource status (Ramesh et al. 2016), nutritional importance (Minde et al. 2020), pharmacology and medicinal aspects (Al-Snafi 2017), as a forage (Murphy et al. 1999), production constraints (Khan et al. 2020) and omic sciences in lablab (Rai et al. 2018). However, little information on characterization and bruchid resistance has been reported in regards to lablab. This review discusses the status, morphological and molecular characterization, core development; management, mechanism and the gene action of lablab genetic resources. The information generated will pave the way for future research focus, especially concerning farmers' preferred traits.

\section{Nutritional importance of Lablab}

Lablab has important nutritional components required for normal growth and development. It is an inexpensive source of protein and micronutrients as compared to other legumes, attesting to the need for research on it to improve food and nutritional security. These micronutrients include fiber, phosphorus, niacin and thiamin which form an important part of the diets of resource-poor households in the rural setting. These highlighted components emphasize lablab as a potential functional crop to help in combating malnutrition and micronutrient deficiency diseases. Table 1 compares the nutritional value of lablab to that of other related legumes such as Cowpea (Vigna unguiculata (L.) Walp.), Bambara groundnut (Vigna subterranea (L.) Verdc.), Common bean (Phaseolus vulgaris L.), Soybean (Glycine max (L.) Merr.), Chickpea (Cicer arietinum L.) and Lentil (Lens culinaris Medik.).

\section{Germplasm resource conservation of lablab}

Ex situ lablab genetic resources are maintained in various locations across the African, Asian, American, Oceanic and European continents (Table 2). Germplasm conservation of lablab plays a critical role in identifying the existing and unknown crop diversity as well as maintaining the genetic basis to enhance the development of improved varieties. The advances in phenotypic and genotypic studies allow effective and efficient exploration of the germplasm collections present in gene banks. Research focuses on understanding the conservation status is important for future breeding programs.

\section{Characterization of lablab germplasm}

Determining the genetic variation of a particular species is paramount for its improvement. Knowledge of the genetic constitution of given germplasm provides a critical groundwork for further breeding programs (Xu et al. 2017). Several genetic diversity studies on lablab crops have been undertaken. These genetic studies range from the classical methods to the current advanced high throughput genotyping methods that are precise, accurate and generate a large amount of information regarding the crop of interest (Yang et al. 2020).

Lablab breeding has incorporated the application of morphological, biochemical and cytogenetic markers with significant contribution in describing important genes as well as determining the genome size and variability (Farooq et al. 2002). Despite this critical contribution, these markers offer narrow genetic information and thus there is a need for advanced methods that exhibit more complex and precise variability of the genes linked to the most important agronomic traits for lablab breeding (Nadeem et al. 2018). The discovery of DNA markers enabled the prediction of individual and population genetic information by detecting the polymorphism existing among the alleles of a given gene (Nadeem et al. 2018).

Germplasm collection, characterization and evaluation are paramount for any given breeding program. Germplasm characterization helps to identify preferred traits of interest by the breeders and farmers (Mwenda 2019). Genetic variation can be distinguished based on morpho-physical, biochemical and DNA-based markers to describe the extent of evolutionary divergence and similarities. The research status in terms of characterization in lablab is discussed below. Most of the research is focused on morphological and DNA-based characterization. 
Table 1 A summary of the comparison of the nutritional composition of lablab with other legumes Source: Adopted and modified from (Ganesan et al. 2017; Tolera 2006; Wallace et al. 2016)

\begin{tabular}{|c|c|c|c|c|c|c|c|}
\hline Component & Lablab & Cowpea & Bambara groundnut & Common bean & Soybeans & Chickpea & Lentils \\
\hline Carbohydrates (g) & 62 & 61 & 61 & 60 & 8.36 & 27.42 & 20.13 \\
\hline Fiber $(\mathrm{g})$ & 8.6 & 5.4 & 4.8 & 4.4 & 6 & 7.6 & 7.9 \\
\hline Fat $(\mathrm{g})$ & 1 & 1.4 & 6.2 & 1.5 & 8.97 & 2.59 & 0.38 \\
\hline Protein $(\mathrm{g})$ & 22.8 & 22.5 & 18.8 & 21.7 & 18.21 & 164 & 9.02 \\
\hline Calcium (mg) & 90 & 104 & 62 & 120 & 102 & 49 & 19 \\
\hline Iron $(\mathrm{mg})$ & 9 & N/A & 12.2 & 8.2 & 5.14 & 2.89 & 3.33 \\
\hline Phosphorus (mg) & 328 & 416 & 276 & 323 & 245 & 168 & 180 \\
\hline Ascorbic acid (mg) & trace & 2 & trace & 1 & 1.7 & 1.3 & 1.5 \\
\hline$\beta$-carotene $(\mathrm{mg})$ & N/A & 70 & 10 & 10 & 9 & 27 & 8 \\
\hline Niacin (mg) & 2.3 & 4 & 1.8 & 2.4 & 0.399 & 0.526 & 1.06 \\
\hline Riboflavin (mg) & 0.1 & 0.9 & 0.1 & 0.2 & 0.285 & 0.063 & 0.073 \\
\hline Thiamin (mg) & 0.5 & 0.1 & 0.5 & 0.4 & 0.155 & 0.116 & 0.169 \\
\hline
\end{tabular}

Table 2 Lablab genetic resources in different gene banks Source: Kirkhouse Trust (2019); Maass et al. (2010);Ojiewo et al (2010); Ramesh and Byre Gowda (2016)

\begin{tabular}{|c|c|c|c|}
\hline Continent & Country and Institutions involved & $\begin{array}{l}\text { Acc. } \\
\text { No }\end{array}$ & References \\
\hline \multirow[t]{8}{*}{ Asia* } & South-east Asia (Other than Bangladesh \& India) & 82 & (BI 2008) \\
\hline & South Asia & 93 & (BI 2008) \\
\hline & Philippines & 209 & (Engle 2000) \\
\hline & National Bureau of Plant Genetic Resources (NBPGR), India & 221 & (BI 2008) \\
\hline & China & 410 & (BI 2008) \\
\hline & World Vegetable Research and Development Centre (AVRDC), Taiwan & 447 & (AVRDC 2009) \\
\hline & Bangladesh & 551 & (Islam 2008) \\
\hline & University of Agricultural Sciences (UAS)- Bengaluru, India* & 650 & (BI 2008) \\
\hline \multirow[t]{5}{*}{ Africa* } & $\begin{array}{l}\text { Sub-Saharan Africa including International Institute of Tropical Agriculture (IITA), } \\
\text { Nigeria }\end{array}$ & 67 & (BI 2008) \\
\hline & World Vegetable Centre, Eastern and Southern Africa, Arusha-Tanzania & 73 & (Ojiewo et al. 2010) \\
\hline & Ethiopia including International Livestock Research Institute (ILRI) & 403 & (BI 2008) \\
\hline & Kenya & 403 & (BI 2008) \\
\hline & $\begin{array}{l}\text { Nelson Mandela African Institutions of Science \& Technology (NM-AIST), } \\
\text { Tanzania* }\end{array}$ & 450 & $\begin{array}{l}\text { (Kirkhouse Trust } \\
\text { 2019) }\end{array}$ \\
\hline Oceania & Commonwealth Scientific and Industrial Research Organization (CSIRO), Australia & 104 & BI (2008) \\
\hline \multirow[t]{2}{*}{ America } & United States, Department of Agriculture (USDA) & 52 & (BI 2008) \\
\hline & Europe & 82 & (BI 2008) \\
\hline \multirow[t]{2}{*}{ Europe } & South America & 134 & (GRIN 2009) \\
\hline & Total & 4251 & \\
\hline
\end{tabular}

(Acc. No = Accession Number)

*The largest world collections of lablab germplasm are reported in Asia at UAS Bengaluru, India while in Africa is held at NMAIST, Tanzania. This demonstrates that Africa has fewer lablab collections than Asia 
Morphological characterization

Morphological characterization is based on visual observations of growth habits and structure of plants across a variety of edaphic factors. The variation of major qualitative and quantitative characteristics is entirely responsible for crop improvement in lablab. Byregowda et al. (2015) developed a lablab descriptor with 29 qualitative characters and 41 quantitative characters on a study of 650 accessions depicting the presence of a wide range of phenotypic characters. These morphological variations depend on the vegetative, inflorescence, fruit and seed characters of the lablab. Descriptors help to maintain the genetic purity and identity of a given crop, allow ease of varietal identification and reduce duplication. Lablab exhibits a wide morphological difference in most of its parameters, such as leaf color, leaf vein color, stem pigmentation, flower, pod and seed color and growth habit. Some of the photos of the different seed and flower morphology are as shown below in Fig. 1.

Genetic diversity analysis contributes significant information for breeding and crop improvement. The initial diversity studies involved the application of
Mahalanobis D statistics to determine the variation of 48 Indian bean genotypes (Chaitanya et al. 2013). In this study, the maximum divergence was exhibited in protein content, inflorescence number per flower, pod length and pod number per plant respectively. Similar results were observed on sixty-one (61) genotypes in Bangladesh (Shibli et al. 2021). This generated critical information on hybridization for developing elite recombinants.

Characterization of a germplasm resource as per morphological characters provides knowledge and information to researchers and breeders on the potential to tap and utilize in improving their genetic value. Lablab has high plasticity and is grown across different agro-ecological zones. This has enabled the presence of wide variation of the morphological and agronomic characters and enhance adaptability to the environment. Understanding the existing genetic diversity allows the development of new and improved varieties with farmers' preferred traits. Lablab has been characterized by several agromorphological factors, as illustrated in Table 3 below.

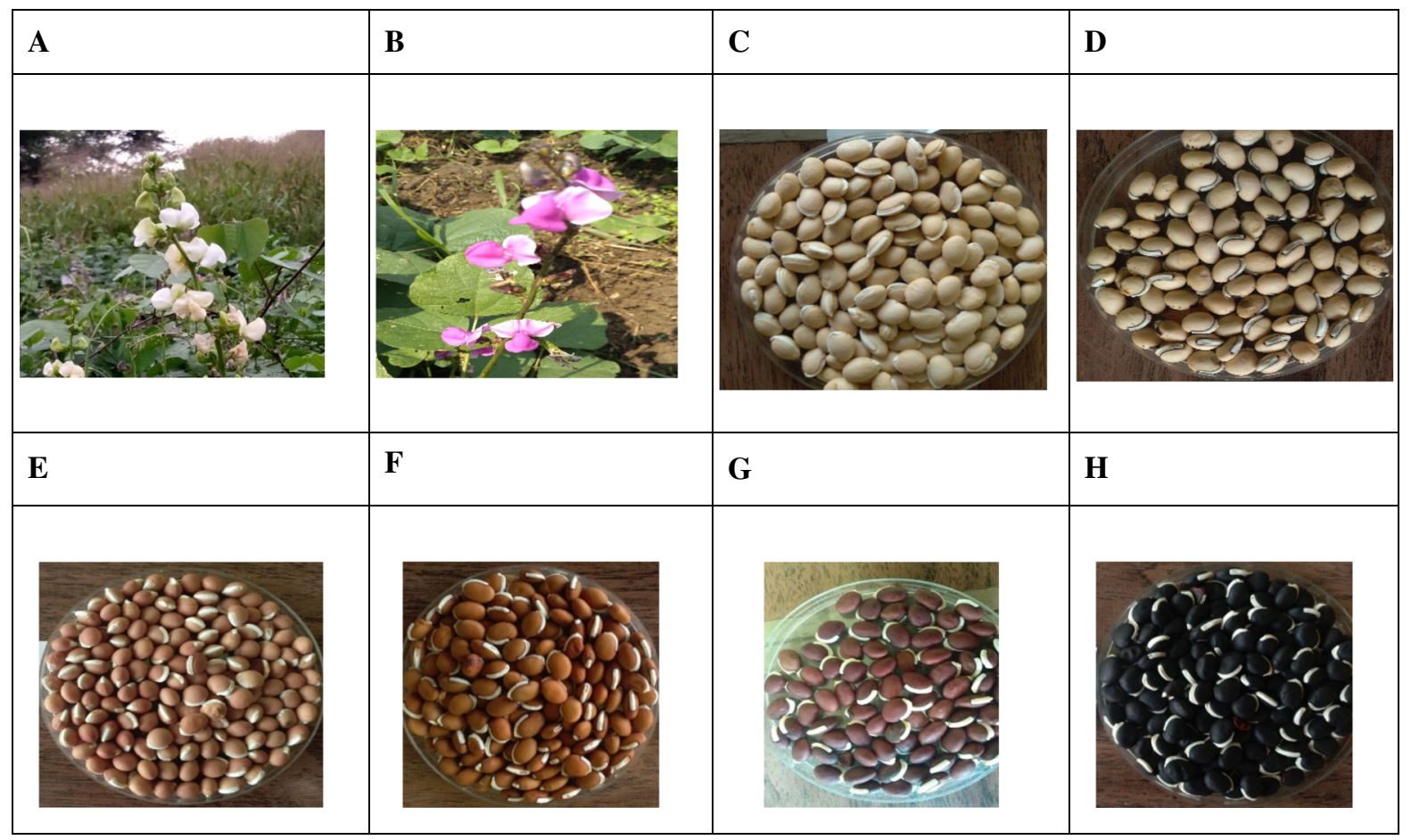

Fig. 1 Diversity in flower and seed morphology of lablab (a) White flowers color (b) Purple flowers (c) White seed color (d) White seed with black hilum edges (e) Cream seed color (f) Brown seed color (g) Red seed color (h) Black seeds 
Table 3 Morphological characterization of lablab traits in different countries

\begin{tabular}{|c|c|c|c|}
\hline Traits & $\begin{array}{l}\text { No. of } \\
\text { Accessions }\end{array}$ & Country & Reference \\
\hline 5 quantitative and 9 qualitative characters & 12 & India & $\begin{array}{l}\text { (Chattopadhyay } \\
\text { et al. 2010) }\end{array}$ \\
\hline 21 quantitative traits as per (Byregowda et al. 2015) & 41 & Tanzania & $\begin{array}{l}\text { (Chawe et al. } \\
\text { 2019) }\end{array}$ \\
\hline $\begin{array}{l}\text { Leaf vein pigmentation, growth habit, branching habit, stem color, flower color, pod } \\
\text { color and characters, such as size, shape, weight and seed number per pod }\end{array}$ & 63 & India & $\begin{array}{l}\text { (Naghera et al. } \\
\text { 2016) }\end{array}$ \\
\hline 17 quantitative and qualitative characters (Byregowda et al. 2015) & 37 & India & (Patil et al. 2015) \\
\hline $\begin{array}{l}\text { Seed (length, width, weight, and thickness) leaf (length, and width), pod (length and } \\
\text { width) }\end{array}$ & 15 & Indonesia & $\begin{array}{l}\text { (Purwanti et al. } \\
\text { 2019) }\end{array}$ \\
\hline Leaf size,, vine color, flower color, pod(color, shape and type) and seed color & 23 & Nepal & (Ram et al. 2016) \\
\hline Stem color, leaf size, flower color, pod color, pod size, seed size, seed weight & 14 & India & $\begin{array}{l}\text { (Singh \& } \\
\quad \text { Abhilash 2019) }\end{array}$ \\
\hline 21 qualitative traits and 20 quantitative traits & 650 & India & $\begin{array}{l}\text { (Vaijayanthi et al. } \\
\text { 2015) }\end{array}$ \\
\hline
\end{tabular}

Table 4 Biochemical characterization of lablab in different countries

\begin{tabular}{|c|c|c|c|}
\hline Biochemical character & Country & Accessions & Reference \\
\hline Digestibility, proximate and energy composition & Nigeria & 1 & $\begin{array}{l}\text { (Abeke et al. } \\
\text { 2012) }\end{array}$ \\
\hline Fatty acid and sugars & $\begin{array}{l}\text { United States of } \\
\text { America }\end{array}$ & 17 & $\begin{array}{l}\text { (Bhardwaj } \\
\text { et al., 2019) }\end{array}$ \\
\hline Water, ash, lipid, protein, and amylose contents & Indonesia & 12 & $\begin{array}{l}\text { (Purwanti et al. } \\
\text { 2019) }\end{array}$ \\
\hline Proteins and essential fatty acids & Bangladesh & 1 & $\begin{array}{l}\text { (Hossain et al. } \\
\text { 2016) }\end{array}$ \\
\hline $\begin{array}{l}\text { Proximate composition, seed protein fractions, vitamins, amino acid profile, } \\
\text { mineral profiles, antinutritional factors and fatty acid profiles }\end{array}$ & Bangladesh & 2 & $\begin{array}{r}\text { (Kalpanadevi } \\
\text { et al. 2013) }\end{array}$ \\
\hline Dry matter, protein, fat and ash, phytates, tannins and trypsin inhibition & Kenya & 3 & $\begin{array}{l}\text { (Kilonzi et al. } \\
\text { 2017) }\end{array}$ \\
\hline Sensory characteristics and volatile compounds & Kenya & 24 & $\begin{array}{l}\text { (Kimani et al. } \\
\text { 2019) }\end{array}$ \\
\hline Nutritional and antioxidant properties & India & 21 & (Rai et al. 2014) \\
\hline Chemical, physicochemical and starch components & South Africa & 1 & $\begin{array}{l}\text { (Naiker et al. } \\
\text { 2020) }\end{array}$ \\
\hline $\begin{array}{l}\text { Phytochemical constituents, proximate composition, anti-nutritional factors and } \\
\text { mineral composition }\end{array}$ & Nigeria & 1 & $\begin{array}{l}\text { (Sulaiman et al. } \\
\text { 2018) }\end{array}$ \\
\hline Nutritive and anti-nutrient contents & South Africa & 1 & $\begin{array}{l}\text { (Washaya et al. } \\
\text { 2018) }\end{array}$ \\
\hline
\end{tabular}


Biochemical characterization

Description of the biochemical factors present in lablab species is fundamental. However, limited biochemical characterization has been done (Table 4). Estimation of biochemical components is essential to establish a breeding strategy for the compounds desired by the end-user. Lablab is associated with anti-nutritional factors that hinder its consumption. Characterization guides towards breeding of varieties with consumer-preferred components that will allow their adoption, consumption and utilization. There is a need to characterize biochemical compounds present in lablab to document existing variation among different germplasms.

\section{Molecular characterization of lablab}

Molecular characterization provides comprehensive information on genetic information of agricultural traits as well as diversity within and between accessions that is fundamental for marker-assisted and genomic breeding programs. The discovery of molecular markers paved the way for the description of species at the DNA level. Considerable number of molecular markers have been applied to determine the genetic diversity, relationships and describe population structure in lablab as shown in Table 5. Most of the studies reveal a narrow genetic variation among studied genotypes. For an effective and efficient breeding system, a wide genetic variation of genotypes is preferred to allow the development of new varieties.

In addition to the above-mentioned DNA markers, genomic and Next Generation Sequencing (Rapholo et al. 2020) approaches have proved pivotal in hastening variety development, release and crop improvement of lablab. Lablab is among the 101 crops selected for the high throughput-sequencing program under the African Orphan Crops Consortium (AOCC) for crop improvement (Hendre et al. 2019). The whole-genome characterization allows Single Nucleotide Polymorphism (SNPs) studies essential for crop genomics and identifying the trait of interest in the genome. This is vital for crop improvement, variety development and breeding for biotic and abiotic stresses.

\section{Core collection of lablab}

Core collection refers to a limited set of accessions selected to represent the maximum genetic diversity within a given set of germplasm pools with a minimum level of redundancy (Brown 1989b; van Hintum et al. 2000). It is recommended not to exceed $10 \%$ of the initial collection as well as being not more than 2000 entries (Brown 1989a, 1989b). Core collection plays an important role in varietal development. Effective and efficient plant breeding requires the use of a representative sample that possesses the desired traits. Breeding of crops for biotic and abiotic stresses is a critical venture, especially with the twin challenges of an ever-spiraling population and the impacts of climate change. Phenotyping for important traits in a whole collection of germplasms is an expensive and labor-intensive venture. To minimize this cost, core collection evaluation allows for the description of desired agronomic alleles in germplasms and also the study of existing genetic variation (Rivera et al. 2018).

Limited information on core collection in lablab has been documented. Pengelly et al. (2001) studied agro-morphological attributes of (122) Australia and (127) Ethiopian dolichos lablab accessions and grouped them into two: subsp. purpureus and subsp. uncinatus with the most significant variation occurring in the Ethiopian accessions. This study contributes to the assumption of Eastern Africa being the center of origin of lablab. Similarly, a core collection of 64 representative accessions was developed based on 21 qualitative and 20 quantitative traits from 644 accessions in India. During the study, a comparison of standard stratified clustering and the Heuristic approach was performed to determine the efficiency of developing a representative sample and reported the Heuristic approach to be more appropriate (Vaijayanthi et al. 2015).

The above-highlighted core collections of lablab are currently being researched and documented in regards to its crop improvement. Despite the existence of large germplasm collections, there is a lack of developed core collections in Africa. There is a need to research existing lablab accessions in Africa and to document the core collections which can serve as the foundation for lablab breeding, crop improvement, production and consumption. 
Table 5 A summary of the results of the studies genetic diversity of lablab, molecular markers used, country of the study, genetic material used, key findings and references

\begin{tabular}{|c|c|c|c|c|}
\hline $\begin{array}{l}\text { Molecular } \\
\text { marker }\end{array}$ & Genetic material & Country & Key findings & References \\
\hline AFLP & 50 accessions & Kenya & $\begin{array}{l}\text { Narrow genetic base and extensive germplasm } \\
\text { exchange of lablab amongst farmers }\end{array}$ & $\begin{array}{l}\text { (Esther et al. } \\
\text { 2012) }\end{array}$ \\
\hline AFLP & $\begin{array}{l}103 \text { accessions (Wild } \\
\text { and cultivated) }\end{array}$ & Australia & $\begin{array}{l}\text { Domestication pathway and distribution of lablab from } \\
\text { Africa to Asia }\end{array}$ & $\begin{array}{l}\text { (Maass et al. } \\
\text { 2005) }\end{array}$ \\
\hline AFLP & 40 accessions & India & High genetic diversity of the lablab accessions & $\begin{array}{l}\text { (Patil et al. } \\
\text { 2009b) }\end{array}$ \\
\hline AFLP & 33 accessions & Germany & $\begin{array}{l}\text { Lablab accessions from East Africa showed distinct } \\
\text { agro-morphological characters }\end{array}$ & $\begin{array}{l}\text { (Tolera et al. } \\
\text { 2008) }\end{array}$ \\
\hline AFLP & 78 accessions & India & $\begin{array}{l}\text { Narrow genetic diversity of Indian accessions as } \\
\text { compared to African accessions }\end{array}$ & $\begin{array}{l}\text { (Venkatesha et al. } \\
\text { 2007) }\end{array}$ \\
\hline DArT & 65 accessions & Uganda & $\begin{array}{l}\text { Narrow genetic diversity of Uganda, CIAT and ILRI } \\
\text { accessions }\end{array}$ & $\begin{array}{l}\text { (Sserumaga et al. } \\
\text { 2021) }\end{array}$ \\
\hline EST-SSR & 19 accessions & China & SSR as a vital molecular tool for breeding of lablab & $\begin{array}{l}\text { (Huang et al. } \\
\text { 2021) }\end{array}$ \\
\hline EST-SSR & 2 accessions & China & Application of SSR in genetic diversity studies & (Yao et al. 2012) \\
\hline EST-SSR & 459 accessions & China & Narrow genetic diversity of Chinese lablab accessions & $\begin{array}{l}\text { (Zhang et al. } \\
\text { 2013) }\end{array}$ \\
\hline ISSR & 6 genotypes & Sudan & ISSR allows discrimination of lablab genotypes & $\begin{array}{l}\text { (Abdallah et al. } \\
\text { 2015) }\end{array}$ \\
\hline RAPD & 15 genotypes & India & Wide genetic variation among studied genotypes & $\begin{array}{l}\text { (Gnanesh et al. } \\
\text { 2005) }\end{array}$ \\
\hline RAPD & 11 accessions & Bangladesh & RAPD clearly distinguishes genetic diversity & $\begin{array}{l}\text { (Sanaullah et al. } \\
\text { 2012) }\end{array}$ \\
\hline RAPD & 10 accessions & India & RAPD can differentiate closely related species & $\begin{array}{l}\text { (Singh Kudesia } \\
\text { et al. 2019) }\end{array}$ \\
\hline $\begin{array}{l}\text { RAPD, ISSR } \\
\text { and SSR }\end{array}$ & 20 accessions & India & SSR most preferred for genetic diversity & $\begin{array}{l}\text { (Dholakia et al. } \\
\text { 2019) }\end{array}$ \\
\hline $\begin{array}{l}\text { RAPD, ISSR } \\
\text { and SSR }\end{array}$ & 39 accessions & India & Close relatedness among Indian genotypes & $\begin{array}{l}\text { (Saravanan et al. } \\
\text { 2013) }\end{array}$ \\
\hline $\begin{array}{l}\text { RFLP, } \\
\text { RAPDs }\end{array}$ & $119 \mathrm{~F} 2$ individuals & Australia & Linkage map construction & $\begin{array}{l}\text { (Konduri et al. } \\
\text { 2000) }\end{array}$ \\
\hline SSR & 299 accessions & Thailand & Low genetic diversity of Thailand lablab accessions & $\begin{array}{l}\text { (Amkul et al. } \\
\text { 2021) }\end{array}$ \\
\hline SSR & 96 accessions & Kenya & Narrow genetic diversity of Kenyan lablab accessions & $\begin{array}{l}\text { (Kamotho et al. } \\
\text { 2016) }\end{array}$ \\
\hline SSR & 16 accessions & India & Genetic diversity exists in the tested genotypes & $\begin{array}{l}\text { (Keerthi et al. } \\
\text { 2018) }\end{array}$ \\
\hline SSR & 143 accessions & India & $\begin{array}{l}\text { Evaluation of cross-species SSR markers for genetic } \\
\text { diversity of lablab }\end{array}$ & (Rai et al. 2016) \\
\hline SSR & 91 accessions & $\begin{array}{l}\text { United } \\
\text { Kingdom }\end{array}$ & Lablab originated from East Africa & $\begin{array}{l}\text { (Robotham et al. } \\
\text { 2017) }\end{array}$ \\
\hline SSR & 13 genotypes & Kenya & Narrow variability among the genotypes evaluated & $\begin{array}{l}\text { (Shivachi et al. } \\
\text { 2012) }\end{array}$ \\
\hline SSR & 2 genotypes & India & $\begin{array}{l}\text { SSR markers can efficiently show polymorphism } \\
\text { within lablab species }\end{array}$ & $\begin{array}{l}\text { (Shivakumar } \\
\text { et al. 2015) }\end{array}$ \\
\hline SSR & 48 accessions & India & Narrow genetic diversity of the studied populations & $\begin{array}{l}\text { (Wang et al. } \\
\text { 2007) }\end{array}$ \\
\hline
\end{tabular}




\section{Bruchid studies in lablab}

Bruchids (Callosobruchus spp) belong to the order Coleoptera, family Bruchidae and genus Callosobruchus and consist of over 1300 species with 20 of them reported to adversely affect legume crops in the developing countries (Credland 1994). The main species that attack legumes during storage include $C$. chinensis Fabricius, C. maculatus Fabricius, C. theobromae, C. analis Linnaeus, C. phaseolin, Acanthoscelides obtectus and Zabrotes subfasciatus (Credland 1994). The bruchids feed on leguminous crops in and off the field and are the most destructive pests in storage (Southgate 1979). The dried leguminous seeds contain carbohydrates, proteins, and lipids easily consumed by bruchids. The adult lays eggs on the pod or seed surface, which hatch into larvae and burrow through the pods into the seed, feeding on the nutrient-rich cotyledon. The larvae grow utilizing the food substances and also damage the embryo in the seed and the adult bruchids emerge out by creating holes on the seed surface (Atanda et al. 2012; Tripathy 2016). Therefore, the physical and physiological seed quality is affected (Chipungahelo et al. 2007; Ebinu et al. 2016; Lawrence et al. 2017), through primary infestation and secondary infestation by contamination with their excreta and mold growth (War et al. 2017) and thus decreases the market value (Mishili et al. 2011).

Similar to other legumes, Lablab is also attacked by bruchids. A study of $C$. maculatus on 22 lablab accessions reported four accessions (12,022, 12,028, 12,003 and 12,167) with a low number of adults emerging and prolonged development period which is associated with relative resistance (Legume Society 2016). In an experiment involving 16 lablab genotypes, GI 187 had the lowest egg number, lowest damaged seeds, least adult emergence, prolonged growth period and the lowest growth index, an indication of the presence of resistance to C. theobromae (Naveena et al. 2011). Additionally, only 3 genotypes (GL 63, GL 77 and GL 233) in a seed lot of 28 genotypes showed reduced attack by $C$. theobromae exhibited by the low number of eggs, lowest adult emergence, least damaged seeds and lowest seed infestation which is correlated with resistance. Screening of 133 germplasm accessions against $C$. chinensis revealed 11 genotypes (GL 1, GL24, GL 61, GL 69, GL 82, GL 89, GL 121, GL 135, GL 196, GL412 and
GL 413) with $<10 \%$ damage which points to the presence of resistance of the genotype (Jagadeesh et al. 2008). It is clear from the preceding studies that lablab bruchid resistance studies have been limited to screening and identification of resistant varieties only. Screening allows the identification of resistant genotypes to be used in developing varieties. There is a knowledge gap on the host plant resistance mechanism and inheritance of genetic resistance. Further studies are paramount to provide information for breeding programs.

\section{Bruchid management}

Bruchid control methods include chemicals, cultural, botanical and biocontrol. Chemical use includes pirimiphos methyl (Odeyemi et al. 2006), organophosphate (Sharma et al. 2016; Subekti et al. 2019) carbamates (Ebadollahi et al. 2012) and Organochlorines (Bogamuwa et al. 2002). Chemical control has been associated with environmental pollution and food safety concerns (Tripathy 2016), increasing the cost of production and hence minimizing the profitability of the farmers (Srinivasan 2014) and developing resistance by the pest. Cultural control methods such as appropriate time of planting and harvesting, harvesting frequency, weeding of the bruchid host plant in the field, crop hygiene (Kesho 2019; Van Huis 1991) and application of ash, sand, kaolin and clay on the seed surface (Alice et al. 2013; Srinivasan 2014) have contributed towards managing bruchids. However, cultural methods require prolonged planning procedures coupled with large quantities of the above substances to be applied to the seed.

Application of pesticidal plant products such as leaves of Tephrosia vogelii Hook (Fabaceae), Alstonia boonei De Wild (Apocynaceae), Pawpaw (Asimina triloba (L.) Dunal) and Hyptis suaveolens (L.) Poit (Lamiaceae), (Ehimemen and Salisu 2020), Tithonia diversifolia (Hemsl.) A. Gray extracts, Jatropha curcas L. seed, Cyperus rotundus L. (Kolawole et al. 2014) Anona (Annona muricata Vell.) seed powder and citrus (Citrus reticulate Blanco) peels (Ibrahim et al. 2018) have been reported to control bruchids in cowpea. Leaf extracts of fresh leaves of Tithonia diversifolia (Hemsl.) A. Gray, Tephrosia vogelii Hook, Lantana camara L. and Vernonia amygdalina Delile in common bean and peas (Mkindi 2016) have proved effective in controlling bruchids. 
Vegetable oils such as olive (Olea europaea L.) and mustard (Brassica spp. and Sinapsis spp.) are all alternative botanicals that have been studied on legumes and showed a positive result in controlling bruchid infestation (Srinivasan 2014). Botanicals degrade easily, are slow in action, does not affect non-target organisms and interfere with seed germination (Yusuf et al. 2011). Biological control strategies include entomopathogenic fungi Metarhizium anisopliae (Metchnikoff) Sorokin and Beauveria bassiana (Bals.-Criv.) Vuill. (Iqbal et al. 2018; Ozdemir et al. 2020). Parasitoids such as Anisopteromalus (Hance 2007), Prostephanus truncates Horn (Helbig 1998) Dinarmus basalis Rondani (Boateng et al. 2008) revealed efficient bruchid management. Some of these biocontrol organisms become an environmental hazard due to their persistence and some develop to be invasive to the environment, posing a threat to the natural inhabitants of the ecosystem.

Limited information on the control methods of bruchids in lablab exists. Application of vegetable oil, powdered detergent, bamboo charcoal, bleach solution, galangal powder and carbaryl in controlling bruchid pest in lablab showed positive results by limiting pest population (Lawrence et al. 2017). However, the application of these treatments reduced seed vigor and germination rate with the oil application killing the seeds (Lawrence et al. 2017). Studies on the application of oil and seed kernel extract of neem ascertain its efficiency in controlling bruchids in lablab (Naveena et al. 2010) but determining the correct concentration and proportions to be applied for control as well as the safety limits of its use. The gap existing in control methods of lablab illustrates the necessity to understand the mechanism of resistance and the gene action which is integral in breeding resistant varieties.

\section{Host plant resistance to bruchids}

Host plant resistance describes the interaction of the pests and the host plant and is usually cumulative and constant. The development of resistant varieties is simple, cost-effective, environmentally friendly and can be applied concurrently with other strategies such as chemical and bio-control. Varietal resistance to pest attack is the most appropriate method since it is efficient, affects target organisms only, sustainable and reduces the cost of production. Studies on host plant resistance to bruchids have been undertaken in soybean (Msiska 2019), common bean (Maro 2017; Tigist et al. 2018), cowpea (Weldekidan 2019), mung bean (L.) R. Wilczek (Somta et al. 2006) and pigeon pea (Cajanus cajan L.) Millsp.) (Mishra et al. 2019). Host plant resistance is categorized into antixenosis (physical/morphological) and antibiosis (biochemical).

\section{Antixenosis}

Antixenosis describes a physical or morphological resistance mechanism possessed by plant/seed to prevent insect colonization that relies on plants for food substances, shelter and oviposition sites. Antixenosis resistance mainly occurs at the initial phase where insects damage the susceptible seed as compared to the resistant seed material thus the number of insects will vary. Morphological characters of seed (surface/texture, color, size, shape, hardness), pod (shape and texture) (Divya et al. 2013; Saruchi et al. 2014; Somta et al. 2007) act as a direct defense strategy against pests growth and development. Oviposition density directly correlates to the population establishment of the pest in the host species.

Seed surfaces significantly influence seed protection. The majority of Callosobruchus species oviposit their eggs on the seed/pod surface, where they hatch into young larvae that penetrate the pod wall into the seed. A hard pod, capsule, or seed and seed coat prevent the newly hatched larva from penetrating the seed (Mei et al. 2009). Small pods or seeds, do not support larva growth to full size due to little food reserves (Somta et al. 2007). Concerning color, black seeds are less preferred by female bruchids for egg oviposition (Somta et al. 2007). Similarly, large and dull seeds are preferred to small and shiny seeds in mung beans during oviposition (Tripathy 2016). Soft and thin seed coated varieties were preferred by $C$. maculatus in cowpea as compared to hard seeded counterparts (Tripathy 2016).

In lablab, studies revealed that female bruchids preferred to oviposit on the surface of bright colored and smooth-surfaced seeds (Prasad et al. 2013b). Similar results of influence on seed parameters like shape, color, thickness and diameter correlate with oviposition by C. theobromae (Naveena et al. 2012; Pawara et al. 2019). Reduced oviposition through 
antixenosis is directly related to low fecundity rate (Kar et al. 2016) and migration of the larva (Seram et al. 2016) or increased juvenile mortality rate of the pest. Morphological characteristics such as seed color, size, texture, hardness and shape could be an indication of the presence of bruchid resistance in lablab but cannot be the only mechanism of resistance.

Testing for antixenosis resistance involves both choice and no-choice situations and is quantified based on oviposition, growth, survival (Stout 2014) and the number of insects infesting the test cultivars (Kogan et al. 1978). Analysis of the antixenosis mechanism describes the behavior of the pest on the seed lot with varying genetic resistance (Keneni et al. 2011). The scanty information on the morphological basis of resistance in lablab pinpoints the need to do further research and evaluation to obtain the characters associated with resistance.

\section{Antibiosis}

Antibiosis refers to the mechanism where plant biochemical compounds/secondary metabolites and anti-nutritional factors hinder insect infestation by influencing its biological activity and establishment (Mishra et al. 2019; Smith 2005). Studies report that plants exude secondary metabolites as a defensive mechanism against insect pests attack (War et al. 2012). Secondary metabolites refer to compounds obtained by biosynthesis of primary compounds such as sugars, lipids, amino acids and simple organic acids (Keneni et al. 2011). They are synthesized into secondary metabolites such as lignins, tannins, phytates, alkaloids, quinines, phenolic acids, saponins and flavonoids found in plant structures such as seed coat and integuments and secrete antinutritional factors such as arcelins, trypsin inhibitors, enzyme inhibitors, lectins, vicilin, cyanogenic glycosides, phytic acid and phaseolin which acts as repellents and feeding inhibitors (Panda et al. 1995). This mechanism leads to reduced larval growth, increased larval mortality, and decreased pupal weights, prolonged larval and pupal development periods, low pupation, low fecundity rates and decreased egg viability (Sharma et al. 2017; War et al. 2013).

Antibiosis mechanisms are evaluated using nochoice tests in which pests or insects are enclosed with the plant or plant materials with restricted movement. The main aspects under study involve the collection of data on the number of dead insects, level of damage to the seed, insect biology, development, fecundity, and survival (Mendesil 2014). Several chemical components within the seed develop synergistic or additive effects on the insects' pests, such as bruchids. The biochemical factors in lablab involve studies on trypsin inhibitors, arcelin, $\alpha$-amylase inhibitors, tannins, peroxidase and vicilin.

Trypsin inhibitors aid in predicting resistance/ vulnerability to bruchid attack in leguminous crops. Low trypsin inhibitors in a variety of Indian pea or grass pea (Lathyrus sativus L.) exhibited reduced bruchid resistance. There is thus a correlation between trypsin inhibitor amounts and C. maculatus attack (Southgate 1979). In Lablab, the correlation is inverse where genotypes with increased chymotrypsin inhibitors and trypsin levels revealed resistance to $C$. maculatus with the brown seeds showing high levels as compared to black seeds (Ignacimuthu et al. 2000). Trypsin inhibitors bind proteolytic enzymes providing a natural defense mechanism against bruchid attack.

Peroxidase (POD) and polyphenol oxidase (PPO) enzymes play a significant role in plant resistance to insect pest attack (He et al. 2011). These enzymes generate reactive oxygen species that transfer defenserelated signals, initiating the hypersensitive reaction and strengthening the cell walls by enhancing lignin formation and cross-linking, thus protecting against attack (De Jager et al. 1996). Evaluation of 12 rice bean genotypes exhibited variation in response to peroxidase activity, suggesting resistance of rice beans against bruchid attack (Pavithravani et al. 2013). Peroxidase catalyzes the oxidation of toxic metabolic compounds which cannot be consumed by the insect pest. In this regard, the pest will not attack the genotype.

In lablab, genotypes with resistance to $C$. theobromae had high peroxidase activity as compared to the susceptible ones (Babu et al. 2011). High peroxidase activity is associated with increased tolerance/resistance of a crop to bruchid attack. Three varieties, GL 187, GL 63, GL 127 and GL 195 revealed high peroxidase and were classified as resistant varieties whereas GL 36, GL 46, GL 102, HA4, HA3 were susceptible due to low levels. Quantification of peroxidase activity in lablab could thus be used as one of the methods of identifying resistant varieties for pre-breeding programs. 
Enzyme inhibitors such as $\alpha$-amylase inhibitors are found in abundance in seeds and other plant parts of most legumes and are reported to interfere with the metabolism of carbohydrates and protein by inactivating the digestive enzymes present in the bruchid gut cells, impairing the digestion and absorption of food substances. Studies reveal the presence of $\alpha$-amylase inhibitors in lablab seed extracts (Janarthanan et al. 1999). Characterization and purification of the $\alpha$ amylase inhibitor from a brown-seeded undomesticated variety of lablab expressed a great amount of resistance to the $C$. maculatus attack while still in the field and during storage (Janarthanan et al. 1999). Evaluation of germplasm resources with potentially high levels of $\alpha$-amylase inhibitor is paramount to breed resistant varieties.

Arcelin is the main seed protein found in indigenous accessions of legumes and exhibits elevated levels of resistance to Callosobruchus spp. (Osborni et al. 1988). Arcelin interferes with the digestion of food by the pest, leading to the death of larvae as a result of starvation. In addition, insects feeding on legumes with high arcelin compounds had lower weight as compared to those from arcelin free, indicating the reduced consumption of beans with arcelin (Duarte et al. 2018). Purified seed extracts of lablab proteins contain different forms of arcelins and related plant defensive proteins (Janarthanan et al. 2008). Several propositions have been given on the insecticidal activity of arcelin-1, with others arguing that the chemical disrupts the epithelial cells in the gut. Others hypothesize the toxicity caused by arcelin results from the interaction of the protein with specific glycosylation present in the gut of the bruchid or by secretion of poorly digestible protein that is harmful to the insect (Janarthanan et al. 2008). Knowledge of this antimetabolic effect is important in developing resistant crops.

Tannins refer to polyphenolics with heavy molecular weights ranging from 500 to $4000 \mathrm{Da}$ and their hydroxyl groups denature proteins, thus precipitating from the solution. They are usually contained between the aleurone layer and outer integument of the seed tissues (Lattanzio et al. 2005). Tannins reduce attacks due to their bitter taste affecting palatability and intake by the insects. It inactivates the enzymes along with the digestive tract and forms complexes with their proteins, hence affecting the consumption. Correlation of tannin levels and C. maculatus resistance on Vigna species (Marconi et al. 1997) and against $C$. chinensis in soybean (Msiska et al. 2019) has been studied. Bruchid-resistant varieties exhibited high tannin levels with low adult bruchid emergence, prolonged development period, least seed weight loss, and delay in growth index (Msiska et al. 2019). However, contrasting results in cowpea genotypes were reported where the resistant genotypes expressed low concentrations of free and condensed tannins while the susceptible ones had the highest levels (Weldekidan 2019). These conflicting results could be speciesspecific as well as the variability in the genotype production environment and thus there is a need to determine each species individually. Lablab contains a wide range of tannins as their chemical constituent (Harsur et al. 2011). There is a need to investigate the potential effect with bruchid resistance. Limited information exists in regards to tannins present in lablab on control of bruchids.

Vicilins or storage globulins refer to specific-chain proteins lacking disulfide bonds that form trimers of subunits with differing molecular masses ranging from (45-53 kD). They usually contain a vast number of genes with the sequences of vicilin subunits from the leguminous family exhibiting a increased degree of sequence similarity pointing to the same evolutionary path (Sales et al. 2000). The bruchid-resistant genotypes possess vicilin that binds to the chitin matrix along the gut membranes of C. maculatus (Sales et al. 2000) and resists proteolysis. Lablab seeds have been studied to contain high levels of vicilin compounds associated with the transfer of insect resistance to the species (Ignacimuthu et al. 2000). Brown seeded varieties possess higher vicilin levels and were categorized as resistant as compared to the dark seeds which had low vicilin levels (Ignacimuthu et al. 2000; Lim 2012; Tripathy 2016). This suggests that increased vicilin in lablab confers bruchid resistance and that more research on a broader range of genetic resources is needed.

Despite the increased emphasis on lablab research, few efforts have been made to study bruchid resistance, particularly in East Africa (Legume Society 2016), where it is thought to be the starting point of domestication forming. Knowledge regarding the presence of resistant genotypes will be pivotal for breeding programs. Determination of sources of bruchid resistance in lablab should incorporate approaches, which provide knowledge in regards to 
physical, morphological, and biochemical compounds responsible for resistance.

\section{Lablab gene action and bruchid resistance}

Studies on the genetics of bruchid resistance and its inheritance are paramount in developing a breeding. Developing resistant lines is regarded as the most appropriate and effective way of controlling bruchids in major crops. Identification of bruchid resistance through screening of gene pools both from local as well as exotic/foreign has been considered to build the base for breeding programs (Tripathy 2016). According to research, the inheritance patterns of resistance are complex because the seed components originated from different sources and hence possess different ploidy levels. The seed coat is obtained from maternal tissues and is diploid while embryo and endosperm tissues are triploid (Tripathy 2016). Information on the existing resistance of lablab to bruchid attack provides a ground for undertaking the breeding towards this trait.

Development of resistant crop varieties relies on the presence of potential genes and their inheritance (Rubiales et al. 2015). Bruchid resistance can be monogenic (single major gene) polygenic (several minor genes) (Togola et al. 2017). Polygenes control several pests and pyramiding them into new varieties is complex. The genetic basis of leguminous crop resistance to storage insects varies from monogenic to oligogenic for pests like C. maculatus and C. chinensis in mungbean (Redden et al. 1983). Normally, additive and dominant genes are responsible for bruchid resistance during the storage of most leguminous species (Somta et al. 2008). Recent studies on major leguminous crops have reported the mechanisms of gene actions on the inheritance of resistance. Msiska et al. (2018) observed the existence of additive and non-additive gene factors that influence soybean resistance to $C$. chinensis. The research also described the maternal effects of the parental genotypes that are core during hybridization. Furthermore, elite progenies from crosses with negative General Combining Abilities (GCA) require further screening and advancing for the release of resistant varieties.

Weldekidan (2019) using a diallel mating scheme revealed the presence of genetic variation of tested cowpea cultivars in relation to their resistance to C. chinensis. GCA and Specific Combining Abilities
(Msiska) analysis showed significance among studied cultivars for number of eggs oviposited, level of insect emergence and the median development period implying that additive and non-additive gene influence the transfer of resistance to cowpea bruchids (Weldekidan 2019). Similar results in other legumes common bean genetic inheritance to Acanthoscelides obtectus Say (Kananji 2007), common bean genotypes for genetic inheritance to C. maculatus (Mwila 2014) have been reported.

Farmers reported the development and release of bruchid-resistant varieties as the most preferred trait concerning lablab production (Chawe et al. 2019). There is still a lack of research on the mechanism of lablab resistance to bruchid attack, and more research is required. In Tanzania, it is necessary to identify the bruchid-resistant sources in germplasm, the biochemical compounds associated with resistance and conduct genetic resistance studies on lablab germplasm.

\section{Conclusion}

Lablab is an agro-morphological diverse crop with multiple uses and adaptability to different agroclimatic conditions. Despite the manifold uses, the research, production, consumption and funding opportunities remain low. Assessment and exploration of genetic diversity present in a given germplasm collection are fundamental for any breeding program. The use of molecular markers and high throughput sequencing techniques have enhanced crop improvements and breeding programs. Increased crop improvement efforts in Africa to develop farmerpreferred cultivars that are high-yielding, early maturing, nutritious for food and feed, drought-tolerant, and bruchid tolerant/pest tolerant are required for successful adoption of lablab by farmers. Research towards focussing on prioritized traits such as yield, maturity; field pest (aphids and pod borers) and storage pest (bruchids) needs to be initiated. Defensive mechanisms possessed by lablab and the mode of inheritance need to be identified to enable the development of bruchid-resistant lines.

Author contributions statement FKL conceptualized the idea of this review and drafted. PBV reviewed and revised the manuscript critically. PAN read, edited and approved the 
manuscript. The manuscript was read and refined by all authors and finalized by FKL.

Data availability statement Not applicable.

\section{Declarations}

Conflict of interest The authors declare no conflicts of interest.

Ethical approval This article does not contain any studies with human participants or animals performed by any of the authors.

\section{References}

Abdallah O, Hamza NB, Dagash Y (2015) Agronomic and evaluation of six lablab bean (Lablab purpureus L.) cultivars. Int J Sci Resh Agric Sci 2(1):7-15

Abeke F, Amodu J, Ogundipe S, Sekoni A, Adeyinka I (2012) Effect of Processing Methods on the Proximate and Energy Composition of Lablab Purpureus (Rongai) Beans. Nigerian J Animal Sci 14:188-196

Alice J, Srikanth N (2013) Non destructive method to manage the most dreaded pest Callosobruchus maculatus (Fab.) in Black gram Vigna mungo L. J Stored Product Postharvest Res 4(2):30-34. https://doi.org/10.5897/JSPPR12.0141

Al-Khayri JM, Jain SM, Johnson DV (2019) Advances in plant breeding strategies legumes, vol 4. Springer, Berlin

Al-Snafi A (2017) The pharmacology and medical importance of Dolichos lablab (Lablab purpureus)-A review. IOSR J Pharm 7(2):22-30. https://doi.org/10.9790/30130702012230

Amkul K, Sukbang JM, Somta P (2021) Genetic diversity and structure of landrace of lablab (Lablab purpureus (L.) Sweet) cultivars in Thailand revealed by SSR markers. J Breed Sci. https://doi.org/10.1270/jsbbs.20074

Atanda S, Aina J, Agoda S, Usanga O, Pessu P (2012) Mycotoxin management in agriculture a review. J Animal Sci Adv 2(Suppl. 3.1):250-260. https://doi.org/10.1081/txr120024089

AVRDC (2009) AVRDC Vegetable genetic resources information system (AVGRIS), Shanhua, Taiwan. Retrieved May 17, 2021, from The world vegetable center website: http://203.64.245.173/avgris/

Babu J, Hegde JN (2011) Influence of Enzymes, Peroxidase and Phenylalanine Ammonia Lyase (PAL) acitivities on the incidence of Bruchid (Callosobruchus Theobromae L.) on selected fieldbean accessions. Int J Agric Sci 1(2):197-199

Bhardwaj HL, Hamama AA (2019) Fatty acids and sugars in lablab seed produced in virginia (A Non-traditional Location). J Agric Sci 11(17):28-34. https://doi.org/10.5539/ jas.v11n17p28

Bhatt L, Samota MK, Nautiyal M (2019) Potential of underutilized, neglected or untrapped vegetables. J Pharmacog Phytochem 8(2):1650-1653

BI (2008) Biodiversity directory of germplasm collections. Retrieved June 9, 2021, from Biodiversity International.
Rome, Italy website: http://www.biodiversityinternational. org/information_Sources/Germplasm_Databases/ Germplasm_collection_Directory/index.asp

Birch A, Simmonds M, Blaney W (1989) Chemical interactions between bruchids and legumes. Adv Legume Biol 29:781-809

Boateng B, Kusi F (2008) Toxicity of Jatropha seed oil to Callosobruchus maculatus (Coleoptera: Bruchidae) and its parasitoid, Dinarmus basalis (Hymenoptera: Pteromalidae). J Appl Sci Res 4(8):945-951

Bogamuwa M, Weerakoon K, Karunaratne S (2002) Insecticide resistance in the bruchid Callosobruchus maculatus, a storage pest of legumes. Ceylon J Sci (biol Sci) 30:55-66

Boit L, Kinyua M, Kiplagat O, Chepkoech E (2018) Evaluating Kenyan Dolichos (Lablab purpureus L.) genotypes for resistance to legume pod borers (Maruca vitrata and Helicoverpa armigera) using morphological markers. Int J Plant Breed Crop Sci 5(1):344-351

Brown A (1989b) Core collections: a practical approach to genetic resources management. Genome 31(2):818-824. https://doi.org/10.1139/g89-144

Brown A (1989a) The case for core collections. In F. O. Brown AHD, Marshall DR, Williams JT (Ed.), The use of plant genetic resources. Cambridge, UK: Cambridge University Press pp 136-156

Byregowda M, Girish G, Ramesh S, Mahadevu P, Keerthi C (2015) Descriptors of Dolichos bean (Lablab purpureus L.). J Food Legumes 28(3):203-214

Calderon M, Pisarev V, Dias R (1987) First record of Callosobruchus phaseoli (Gyllenhal)(Bruchidae: Coleoptera) in Israel. Israel J Entomol 21:123-125

Chaitanya V, Reddy R, Pandravada S, Sujatha M (2013) Genetic divergence in dolichos bean (Lablab purpureus L. Var. Typicus prain) genotypes for yield and yield contributing traits. Electron J Plant Breed 4(4):1340-1343

Chang Y, Liu H, Liu M, Liao X, Sahu SK, Fu Y, Muthemba S (2019) The draft genomes of five agriculturally important African orphan crops. GigaScience 8(3):giy152. https:// doi.org/10.1093/gigascience/giy 152

Chapman MA (2015) Transcriptome sequencing and marker development for four underutilized legumes. Appl Plant Sci 3(2):1400111

Chattopadhyay A, Dutta S (2010) Characterization and identification of selection indices of pole type dolichos bean. Veg Crops Res Bull 73(1):33-45. https://doi.org/10.2478/ v10032-010-0016-9

Chawe KG, Venkataramana PB, Ndakidemi PA (2019) Assessment of farmers' indigenous knowledge and preferences: a tool for sustainable lablab bean (Lablab purpureus L. Sweet) improvement and utilization in Northern Tanzania. J Adv Biol Biotechnol 21(1):1-14. https://doi. org/10.9734/jabb/2019/v21i130081

Chipungahelo M, Misangu R, Reuben S (2007) The effect of sowing bruchid damaged bean (Phaseolus vulgaris L.) seeds on germination, plant development and yield. J Entomol 4:337-341. https://doi.org/10.3923/je.2007.337.341

Credland, P. (1994). Bioassays with bruchid beetles: problems and (some) solutions. In: Stored Product Protection, Held in Canberra, Australia. 17-23 pp 509-516 
Davari S, Gokhale N, Palsande V, Kasture M (2018) Wal (Lablab purpureus L.): An unexploited potential food legumes. Int J Chem Stud 6(2):946-949

Dawson IK, Powell W, Hendre P, Bančič J, Hickey JM, Kindt R, Jamnadass R (2019) The role of genetics in mainstreaming the production of new and orphan crops to diversify food systems and support human nutrition. New Phytol 224(1):37-54. https://doi.org/10.1111/nph.15895

De Jager C, Butôt R, Van Der Meijden E, Verpoorte R (1996) The role of primary and secondary metabolites in chrysanthemum resistance to Frankliniella occidentalis. J Chem Ecol 22(11):1987-1999. https://doi.org/10.1007/ bf02040090

Dholakia H, Mehta D, Joshi M, Delvadiya I (2019) Molecular characterization of Indian bean (Lablab purpureus L.) genotypes. J Pharmacog Phytochem 8(2):455-463

Divya P, Durga KK, Udayababu P (2013) Studies on the effect of biochemical and physico-chemical characters on bruchid (Callosobruchus chinensis L.) resistance in horse gram accessions. J Food Legumes 26(1):70-74

Duarte MAG, Cabral GB, Ibrahim AB, Aragão FJL (2018) An overview of the APA locus and arcelin proteins and their biotechnological potential in the control of bruchids. Agri Gene 8:57-62

Ebadollahi A, Nouri-Ganbalani G, Hoseini SA, Sadeghi GR (2012) Insecticidal activity of essential oils of five aromatic plants against Callosobruchus maculatus F. (Coleoptera: Bruchidae) under laboratory conditions. J Essential Oil Bear Plants 15(2):256-262. https://doi.org/10.1080/ 0972060x.2012.10644044

Ebinu J, Nsabiyera V, Otim M, Nkalubo S, Ugen M, Agona A, Talwana H (2016) Susceptibility to bruchids among common beans in Uganda. Afr Crop Sci J 24(3):289-303. https://doi.org/10.4314/acsj.v24i3.6

Engle LM, and Altoveros NC (2000) Collection conservation and utilization of indigenous vegetables: Proceeding of a Workshop, AVRDC, Shanhua, Tainan, Taiwan, 16-18, 1999 142. Shanhua, Taiwan: Asian vegetable Research and Development Center (AVRDC)

Esther NK, Francis NW, Miriam GK (2012) Molecular diversity of Kenyan lablab bean (Lablab purpureus (L.) Sweet) accessions using amplified fragment length polymorphism markers. Am J Plant Sci 3:311-321. https://doi.org/10. 4236/ajps.2012.33037

Ewansiha S, Ogedegbe S, Ehizogie F (2017) Utilization potentials of lablab (Lablab purpureus (L.) Sweet) and the constraints of field pests and diseases in Nigeria. AgroScience 15:11. https://doi.org/10.4314/as.v15i1.3

Farooq S, Azam F (2002) Molecular markers in plant breeding: concepts and characterization. Pak J Biol Sci 5(10):1135-1140. https://doi.org/10.3923/pjbs.2002.1135. 1140

Forsythe C (2019) Exploring the viability of re-introducing Lablab purpureus (L.) Sweet as a multifunctional legume in northern Tanzania. (Master Dissertation), Swedish University of Agricultural Sciences, Alnarp

Ganesan K, Xu B (2017) Polyphenol-rich lentils and their health promoting effects. Int J Mol Sci 18(11):2390. https://doi. org/10.3390/ijms18112390

Gebreyowhens W (2017) Forage productivity system evaluation through station screening and intercropping of lablab forage legume with maize under Irrigated lands of smallholder farmers. Afr J Agric Res 12(21):1841-1847. https:// doi.org/10.5897/ajar2016.11989

Gnanesh B, Sekhar MR, Gopal K, Reddy KR, Reddy N (2005) Genetic diversity analysis of field bean (Lablab purpureus L.) sweet through RAPD markers. Indian J Plant Gen Resour 18(3):233-235

GRIN (2009) National plant germplasm system. Genetic Resources Information Network, Beltsville, MD, USA. Retrieved August 9, 2019, from http://www.ars-grin.gov/ cgi-bin/npgs/acc/query.pl

Grotelüschen K (2014) Lablab purpureus (L.) Sweet: A promising multipurpose legume for enhanced drought resistance and improved household nutritional status in smallholder farming systems of Eastern Kenya. (Masters Dissertation), Georg-August University Göttingen, Germany

Habib HM, Theuri SW, Kheadr EE, Mohamed FE (2017) Functional, bioactive, biochemical, and physicochemical properties of the Dolichos lablab bean. Food Funct 8(2):872-880. https://doi.org/10.1039/c6fo01162d

Hance T (2007) Potential of Anisopteromalus calandrae (Hymenoptera: Pteromalidae) as biocontrol agent of Callosobruchus maculatus (F.)(Coleopetera: Bruchidae). Afr J Agric Res 2(4):168-172

Harsur M, Babu J, Sudhirkumar, Mangalgikar P (2011) Screening of selected accessions of Dolichos lablab L. to bruchid (Callosobruchus theobromae L.) infestation under field conditions. International Journal on Agricultural Sciences, 1:387-390

He J, Chen F, Chen S, Lv G, Deng Y, Fang W, He C (2011) Chrysanthemum leaf epidermal surface morphology and antioxidant and defense enzyme activity in response to aphid infestation. J Plant Physiol 168(7):687-693. https:// doi.org/10.1016/j.jplph.2010.10.009

Helbig J (1998) Ability of naturally occurring parasitoids to suppress the introduced pest Prostephanus truncatus (Horn)(Coleoptera, Bostrichidae) in traditional maize stores in Togo. J Stored Prod Res 34(4):287-295. https:// doi.org/10.1016/s0022-474x(98)00010-1

Hendre PS, Muthemba S, Kariba R, Muchugi A, Fu Y, Chang Y, Jamnadass R (2019) African Orphan Crops Consortium (AOCC): status of developing genomic resources for African orphan crops. Planta 250(3):989-1003. https://doi. org/10.1007/s00425-019-03156-9

Hossain S, Ahmed R, Bhowmick S, Al Mamun A, Hashimoto M (2016) Proximate composition and fatty acid analysis of Lablab purpureus (L.) legume seed: implicates to both protein and essential fatty acid supplementation. Springerplus 5(1):1-10. https://doi.org/10.1186/s40064016-3587-1

Huang Y, Liu X, Cao D, Chen G, Li S, Wang G, Xu S (2021) Cross-species amplification of common bean (Phaseolus vulgaris) EST-SSRs within hyacinth bean, pea and soybean. Legume Research: An International Journal, 44(3) https://doi.org/10.18805/lr-574

Ibrahim IH, Iro II, Yaroson AY, and Idris J (2018) Efficacy of selected botanicals against cowpea weevils (Callosobruchus maculatus F.) on stored cowpea (Vigna unguiculata (L) Walp). International Journal of Scientific and 
Research Publications, 8. https://doi.org/10.29322/ijsrp.8. 10.2018.p8246

Ignacimuthu S, Janarthanan S, Balachandran B (2000) Chemical basis of resistance in pulses to Callosobruchus maculatus (F.)(Coleoptera: Bruchidae). J Stored Prod Res 36(1):89-99. https://doi.org/10.1016/s0022474x(99)00031-4

Iqbal M, Shaheen FA, Naz F, Raja MU, Fiaz M, and Nadeem M (2018) Management of Callosobruchus chinensis 1.(Coleoptera: Bruchidae) in stored chickpea grains by using entomopathogenic fungi. Pakistan Journal of Agricultural Research, 31(4). https://doi.org/10.17582/journal. pjar/2018/31.4.408.418

Islam MT (2008) Morpho-agronomic diversity of hyacianth bean [Lablab purpureus (L.)] accessions from Bangladesh. In: Plant Genetic Resources Newsletter, pp 73-78

Jagadeesh B, CS, Byregowda M, and Girish G (2008) Screening of Dolichos germplasm for pod borers and bruchids. Environmental and Ecology, 26(4C):2288-2290

Janarthanan S, Venugopal K, Ignacimuthu S (1999) Purification and characterisation of $\alpha$-amylase inhibitor from seeds of a wild variety of Lablab purpureus that show resistance to the bruchid Callosobruchus maculatus. Indian J Exp Biol 37(8):778-781

Janarthanan S, Suresh P, Radke G, Morgan TD, Oppert B (2008) Arcelins from an Indian wild pulse, Lablab purpureus, and insecticidal activity in storage pests. J Agric Food Chem 56(5):1676-1682. https://doi.org/10.1021/jf071591g

Jiang G-L (2013) Molecular markers and marker-assisted breeding in plants. Plant Breed Lab o Fields. https://doi. org/10.1007/978-3-319-22521-0_15

Joshi BK, Shrestha R, Gauchan D, Shrestha A (2020) Neglected, underutilized, and future smart crop species in Nepal. J Crop Improv 34(3):291-313. https://doi.org/10.1080/ 15427528.2019.1703230

Kalpanadevi V, Mohan V (2013) Nutritional and anti nutritional assessment of under utilized legume D. lablab var. vulgaris L. Bangladesh J Sci Ind Res 48(2):119-130. https://doi. org/10.3329/bjsir.v48i2.15743

Kamotho GN, Kinyua MG, Muasya RM, Gichuki ST, Wanjala, BW, Kimani EN, and Kamau EN (2016) Assessment of genetic diversity of Kenyan dolichos bean (Lablab purpureus L. Sweet) using simple sequence repeat (SSR) markers. International Journal of Agriculture, Environment and Bioresearch, 1(1)

Kananji GAD (2007) A study of bruchid resistance and its inheritance in Malawian dry bean germplasm. (Ph. D Dissertation), University of Kwa Zulu Natal, South Africa

Kar A, Ganguli J (2016) Fecundity and preferential oviposition by pulse beetle, Callosobruchus maculatus $\mathrm{F}$ on chickpea (Cicer arietinum L.) var. Dollar. Legume Res Int J 39(2):310-314

Keerthi CM, Ramesh S, Byregowda M, Vaijayanthi PV, Mangalagowri N, Babu M, Mohan Rao A (2016) Identification of putative parents for developing populations for mapping genomic regions controlling economically important traits in dolichos bean (Lablab purpureus L.) var. Lignosus 22:S119-S124

Keerthi C, Ramesh S, Byregowda M, Vaijayanthi P (2018) Simple Sequence Repeat (SSR) Marker assay-based genetic diversity among dolichos bean (Lablab purpureus
L. Sweet) advanced breeding lines differing for productivity per se traits. Int $\mathrm{J}$ Curr Microbiol Appl Sci 7(5):3736-3744

Keneni G, Bekele E, Getu E, Imtiaz M, Damte T, Mulatu B, Dagne K (2011) Breeding food legumes for resistance to storage insect pests: potential and limitations. Sustainability 3(9):1399-1415. https://doi.org/10.3390/ su3091399

Kesho A (2019) A Review on Integrated Management of Callosobruchus chinensis (Coleoptera: Bruchidae) on Faba bean. Int J Novel Res Life Sci 6(4):1-9

Khan AUM, Choudhury AR, Talucder MSA, Hossain MS, Ali S, Akter T, Ehsanullah M (2020) Constraints and solutions of country bean (Lablab purpureus L.) production: a review. Acta Entomol Zool 1(2):37-45

Kilonzi SM, Makokha AO, Kenji GM (2017) Physical characteristics, proximate composition and anti-nutritional factors in grains of lablab bean (Lablab purpureus) genotypes from Kenya. J Appl Biosci 114(1):11289-11298. https:// doi.org/10.4314/jab.v114i1.2

Kimani E, Matasyoh J, Kinyua M, Wachira FN (2019) Characterisation of volatile compounds and flavour attributes of Lablab purpureus bean accessions. Afr $\mathrm{J}$ Biotech 18(24):518-530. https://doi.org/10.5897/ajb2017.15993

Kogan M, Ortman EF (1978) Antixenosis-a new term proposed to define Painter's "nonpreference" modality of resistance. Bull ESA 24(2):175-176. https://doi.org/10.1093/besa/24. 2.175

Kolawole AO, Kolawole AN (2014) Insecticides and bio-insecticides modulate the glutathione-related Antioxidant defense system of Cowpea storage Bruchid (Callosobruchus maculatus). Int J Insect Sci 6:79-88. https://doi. org/10.1177/IJIS.S18029

Konduri V, Godwin I, Liu C (2000) Genetic mapping of the Lablab purpureus genome suggests the presence of'cuckoo'gene (s) in this species. Theor Appl Genet 100(6):866-871. https://doi.org/10.1007/s001220051363

Kordrostami M, Rahimi M (2015) Molecular markers in plants: concepts and applications. Gen Third Millennium 13:4024-4031

Lattanzio V, Terzano R, Cicco N, Cardinali A, Venere DD, Linsalata V (2005) Seed coat tannins and bruchid resistance in stored cowpea seeds. J Sci Food Agric 85(5):839-846. https://doi.org/10.1002/jsfa.2024

Lawrence B, Bicksler AJ, Duncan K (2017) Local treatments and vacuum sealing as novel control strategies for stored seed pests in the tropics. Agron Sustain Dev 37(2):1-10. https://doi.org/10.1007/s13593-017-0415-0

Legume Society (2016) Hyacinth bean: a gem among legumes: State of the art in lablab purpureus research. Int Legume Soc 13:1-56

Liao C, Lin C (2000) Occurrence of the legume pod borer, Maruca testulalis Geyer (Lepidoptera: Pyralidae) on cowpea (Vigna unguiculata Walp) and its insecticides application trial. Plant Protect Bull (taipei) 42(4):213-222

Lim TK (2012) Edible medicinal and non-medicinal plants, vol 1. Springer, Dordrecht, The Netherlands

Liu Y-M, Shahed-Al-Mahmud M, Chen X, Chen T-H, Liao K-S, Lo JM, Wong C-H (2020) A carbohydrate-binding protein from the edible Lablab beans effectively blocks the 
infections of influenza viruses and SARS-CoV-2. Cell Rep. https://doi.org/10.1016/j.celrep.2020.108016

Maass BL, Jamnadass RH, Hanson J, Pengelly BC (2005) Determining sources of diversity in cultivated and wild Lablab purpureus related to provenance of germplasm by using amplified fragment length polymorphism. Genet Resour Crop Evol 52(6):683-695. https://doi.org/10.1007/ s10722-003-6019-3

Maass BL, Knox MR, Venkatesha S, Angessa TT, Ramme S, Pengelly BC (2010) Lablab purpureus - A crop lost for Africa? Tropical Plant Biol 3(3):123-135. https://doi.org/ 10.1007/s12042-010-9046-1

Marconi E, Ruggeri S, Carnovale E (1997) Chemical evaluation of wild under-exploited Vigna spp. seeds. Food Chem 59(2):203-212. 8146(96)00172-0

https://doi.org/10.1016/s0308-

Maro C (2017) Genetics and mechanisms of Bruchid resistance in selected common bean (Phaseolus vulgaris L.) landraces from Tanzania and Malawi. (Ph. D Dissertation), Sokoine University of Agriculture, Tanzania

Mei L, Cheng X, Wang S, Wang L, Liu C, Sun L, Li H (2009) Relationship between bruchid resistance and seed mass in mungbean based on QTL analysis. Genome 52(7):589-596. https://doi.org/10.1139/g09-031

Mendesil E (2014) Plant-resistance to insect herbivores and semiochemicals: implications for field pea pest management. Retrieved from Alnarp:

Minde JJ, Venkataramana PB, Matemu AO (2020) Dolichos Lablab-an underutilized crop with future potentials for food and nutrition security: a review. Crit Rev Food Sci Nutr. https://doi.org/10.1080/10408398.2020.1775173

Mishili FJ, Temu A, Fulton J, Lowenberg-DeBoer J (2011) Consumer preferences as drivers of the common bean trade in Tanzania: A marketing perspective. J Int Food Agribusiness Market 23(2):110-127. https://doi.org/10. 1080/08974438.2011.558761

Mishra SK, Nag A, Naik A, Rath SC, Gupta K, Gupta AK, Panigrahi J (2019) Characterization of host response to bruchids (Callosobruchus chinensis and C. maculatus) in 39 genotypes belongs to 12 Cajanus spp. and assessment of molecular diversity inter se. J Stored Prod Res 81:76-90. https://doi.org/10.1016/j.jspr.2019.02.001

Mkindi AG (2016) The use of pesticidal plants as environmental friendly practice for field and storage pests' management in Common beans and cowpeas. (Masters Dissertation), Nelson Mandela African Institution of Science and Technology, Arusha, Tanzania

Mondal HA, Roy SK, Hijam L, Chakraborty M, Dutta P, Hath TK (2017) Differential aphid colony establishment in Dolichos lablab varieties correlated with some plant specific factors that impact on aphid fecundity. Am J Plant Sci 8(4):754-769. https://doi.org/10.4236/ajps.2017.84053

Msiska UM, Hailay MG, Miesho BW, Ibanda AP, Tukamuhabwa P, Kyamanywa S, Rubaihayo P (2018) Genetics of resistance in F2 soybean populations for adzuki bean bruchid (Callosobruchus chinensis). J Agric Sci 10(12):1916-9752. https://doi.org/10.5539/jas.v10n12

Msiska MU, Belay MW, Hailay M, Samuel K, Patrick R, Thomas O, Deborah NL (2019) Biochemicals associated with Callosobruchus chinensis resistance in soybean. Afr J Rural Develop 3(3):859-868
Msiska MU (2019) Genetic resistance to adzuki bean bruchid (Callosobruchus chinensis) in soybean. (Ph.D Dissertation), Makerere University, Uganda

Murphy AM, Colucci PE (1999) A tropical forage solution to poor quality ruminant diets: A review of Lablab purpureus. Livest Res Rural Dev 11(2):1999

Mwenda ET (2019) Phenotypic and biochemical screening of sorghum genotypes for growth and rice weevil resistance in Tanzania. (Ph. D Dissertation), Nelson Mandela African Institution of Science and Technology, Arusha, Tanzania

Mwila N (2014) Inheritance of Bruchid (Callosobruchus maculatus) resistence in common beans (Phaseolus vulgaris). (Masters Dissertation), University of Zambia, Zambia

Nadeem MA, Nawaz MA, Shahid MQ, Doğan Y, Comertpay G, Yildız M, Labhane N (2018) DNA molecular markers in plant breeding: current status and recent advancements in genomic selection and genome editing. Biotechnol Biotechnol Equip 32(2):261-285. https://doi.org/10.1080/ 13102818.2017.1400401

Naeem M, Shabbir A, Ansari AA, Aftab T, Khan MMA, Uddin M (2020) Hyacinth bean (Lablab purpureus L.)-An underutilised crop with future potential. Sci Hortic 272:109551. https://doi.org/10.1016/j.scienta.2020. 109551

Naghera Y, Vaddoria M, Mehta D, Chakraborty B (2016) Genetic diversity analysis in lablab bean [Lablab purpureus (L.) Sweet]. Springerplus 5:1-10

Naiker TS, Baijnath H, Amonsou EO, Mellem J (2020) The effect of soaking, steaming, and dehydration on the microstructure, physicochemical properties and in vitro starch digestibility of flour produced from Lablab purpureus (L.) Sweet (hyacinth bean). J Food Process Preserv 44(5):e14430. https://doi.org/10.1111/jfpp.14430

Naveena N, Prashanth K (2012) Correlations between physical characters of seeds and infestation of Callosobruchus theobromae L. Bioinfolet-A Q J Life Sci 9(4b):771-772

Naveena NL, Babu CS, Byregowda M (2010) Evaluation of biopesticides against field bruchid, Callasobruchus theobromae 1. dolichos lablab. J Biopesticides 3(3):622-623

Naveena N, Babu C, Sudhirkumar S, Prashanth K (2011) Performance of Callosobruchus theobromae on different genotypes of fieldbean, Lablab purpureus L. J Entomol Res 35(1):75-77

Ngailo J, Kaihura F, Baijukya F, and Kiwambo B (2001) Land use changes and their impact on agricultural biodiversity in Arumeru, Tanzania. Land Management and Ecosystem Conservation. Tokyo: United Nations University People, pp 1-17

Njarui D, Beattie W, Jones R, Keating B (2004) Evaluation of forage legumes in the semi-arid region of Eastern Kenya. I. Establishment, visual bulk rating, insects pests and diseases incidences of a range of forage legumes. Tropical Subtropical Agroecosyst 4(1):33-55. https://doi.org/10. 1111/j.1365-2494.2010.00764.x

Odeyemi O, Gbaye O, Akeju O (2006) Resistance of Callosobruchus maculatus (Fab.) to pirimiphos methyl in three zones in Nigeria. In: Working Conference on Stored Product Protection, Held in Sao Paulo, Brazil, pp 15-18

Ojiewo C, Tenkouano A, Oluoch M, Yang R (2010) The role of AVRDC - The world vegetable centre in vegetable value chains. Afr J Horticul Sci 3:1-23 
Okumu OO, Muthomi J, Ojiem J, Narla R, Nderitu J (2018) Effect of lablab green manure on population of soil microorganisms and establishment of common bean (Phaseolus vulgaris L.). Am J Agric Sci 5(3):44-54

Osborni TC, Alexander DC, Sun SS, Cardona C, Bliss FA (1988) Insecticidal activity and lectin homology of arcelin seed protein. Science 240(4849):207-210. https://doi.org/ 10.1126/science.240.4849.207

Ozdemir IO, Tuncer C, Erper I, Kushiyev R (2020) Efficacy of the entomopathogenic fungi; Beauveria bassiana and Metarhizium anisopliae against the cowpea weevil, Callosobruchus maculatus F (Coleoptera: Chrysomelidae: Bruchinae). Egypt J Biol Pest Control 30(1):1-5. https:// doi.org/10.1186/s41938-020-00219-y

Panda N, Khush G (1995) Host plant resistance to insects. CAB International, Wallingford

Patil P, Venkatesha S, Ashok T, Gowda T, Gowda MB (2009a) Genetic diversity in field bean as revealed with AFLP markers. J Food Legumes 22(1):18-22

Patil P, Venkatesha SC, Ashok TH, Gowda TKS, Gowda MB (2009b) Genetic diversity in field bean as revealed with AFLP markers. J Food Legumes 22(1):18-22

Patil B, Inamdar A, Bhalekar M, Shinde K (2015) Genetic variability and heritability studies in pole type Indian bean (Lablab purpureus L. Sweet). Veg Sci 42(1):103-104

Pavithravani B, Gowda R, Bhanuprakash K, Ramesh S, Rao MA, Subramanya S, Gireesh C (2013) Biochemical components: An index of bruchid resistance in rice bean [Vigna umbellata (Thunb.) Ohwi and Ohashi]. Legume Res Int J 36(6):582-588

Pawara N, Bantewad S, Patil D (2019) Assessment of different interspecific progenies of mungbean against pulse beetle, Callosobruchus chinensis Linn. And it's influence of seed physical characteristics on infestation. J Entomol Zool Stud 7(1):1335-1344

Pengelly BC, Maass BL (2001) Lablab purpureus (L.) Sweetdiversity, potential use and determination of a core collection of this multi-purpose tropical legume. Gen Resourc Crop Evolut 48(3):261-272. https://doi.org/10.1023/a: 1011286111384

Popoola J, Ojuederie O, Omonhinmin C, Adegbite A (2019) Neglected and underutilized legume crops: Improvement and future prospects. Recent Adv Grain Crops Res. https:// doi.org/10.5772/intechopen.87069

Prasad BR, Babu CJ, Gowda MB (2013a) Screening Dolichos bean (Lablab purpureus L.) genotypes for resistance to pulse beetle Callosobruchus theobromae in laboratory. Curr Biotica 7(3):153-160

Prasad BR, Babu CJ, Gowda MB (2013b) Screening Dolichos bean (Lablab purpureus .L) genotypes for resistance to pulse beetle Callosobruchus theobromae in laboratory. Curr Biotica 7(3):153-160

Purwanti E, Wahyu P, and Ahmad F (2019) Nutritional content characteristics of dolichos lablab L. Accessions in effort to investigate functional food source. In: Proceedings of the 6th International Conference on Community Development (ICCD 2019), Held in October 2019, pp 166-170

Qamar IA, Ahmad M, Riaz G, and Khan S (2014) Performance of summer forage legumes and their residual effect on subsequent oat crop in subtropical subhumid Pothwar, Pakistan. Pakistan Journal of Agricultural Research, 27(1)
Rafalski A (2002) Applications of single nucleotide polymorphisms in crop genetics. Curr Opin Plant Biol 5(2):94-100. https://doi.org/10.1016/s1369-5266(02)00240-6

Rai N, Kumar A, Singh P, Singh M, Datta D, Rai M (2010) Genetic relationship among Hyacinth bean (Lablab purpureus) genotypes cultivars from different races based on quantitative traits and random amplified polymorphic DNA marker. Afr J Biotech 9(2):137-144

Rai N, Rai KK, Tiwari G, Kumar S (2014) Nutritional and antioxidant properties and their inter-relationship with pod characters in an under-exploited vegetable, Indian bean (Lablab purpureus). Indian J Agric Sci 84(9):1051-1055

Rai N, Kumar S, Singh RK, Rai KK, Tiwari G, Kashyap SP, Rai AB (2016) Genetic diversity in Indian bean (Lablab purpureus) accessions as revealed by quantitative traits and cross-species transferable SSR markers. Indian J Agric Sci 86(9):654-660

Rai K, Rai N, Rai SP (2018) Recent advancement in modern genomic tools for adaptation of Lablab purpureus $\mathrm{L}$ to biotic and abiotic stresses: present mechanisms and future adaptations. Acta Physiol Plantarum. https://doi.org/10. 1007/s11738-018-2740-6

Ram BK, Joshi BK, Dahal SP (2016) Diversity analysis and physico-morphlogical characteritics of indigenous germplasm of lablab bean. J Nepal Agric Res Council 2:15-21. https://doi.org/10.3126/jnarc.v2i0.16116

Ramesh S, Byregowda M (2016) Dolichos bean (Lablab purpureus L. Sweet var. Lignosus) genetics and breedingpresent status and future prospects. Mysore J Agric Sci 50(3):481-500

Rana R, Sayem ASM, Sabuz AA, Rahman M, Hos-Sain A (2021) Effect of lablab bean (Lablab purpureus L.) seed flour on the physicochemical and sensory properties of biscuits. Int J Food Sci Agric 5:52-57

Rapholo E, Odhiambo JJO, Nelson WCD, Rötter RP, Ayisi K, Koch M, Hoffmann MP (2020) Maize-lablab intercropping is promising in supporting the sustainable intensification of smallholder cropping systems under high climate risk in southern Africa. Exp Agric 56(1):104-117. https:// doi.org/10.1017/S0014479719000206

Redden R, Dobie PE, Gatehouse A (1983) The inheritance of seed resistance to Callosobruchus maculatus F. in cowpea (Vigna unguiculata L. Walp.). I. Analyses of parental, F1, F2, F3 and backcross seed generations. Aus J Agric Res 34(6):681-695. https://doi.org/10.1071/ar9830681

Rivera A, Plans M, Sabaté J, Casañas F, Casals J, Rull A, Simó J (2018) The Spanish core collection of common beans (Phaseolus vulgaris L.): an important source of variability for breeding chemical composition. Front Plant Sci 9:1642. https://doi.org/10.3389/fpls.2018.01642

Robotham O, Chapman M (2017) Population genetic analysis of hyacinth bean (Lablab purpureus (L.) Sweet, Leguminosae) indicates an East African origin and variation in drought tolerance. Gen Resour Crop Evolut 64(1):139-148. https://doi.org/10.1007/s10722-015-0339y

Rubiales D, Fondevilla S, Chen W, Gentzbittel L, Higgins TJ, Castillejo MA, Rispail N (2015) Achievements and challenges in legume breeding for pest and disease resistance. Crit Rev Plant Sci 34(1-3):195-236 
Sales MP, Gerhardt IR, Grossi-de-Sá MF, Xavier-Filho J (2000) Do legume storage proteins play a role in defending seeds against bruchids? Plant Physiol 124(2):515-522. https:// doi.org/10.1104/pp.124.2.515

Sanaullah BM, Mohammad Z, Mizanur RM (2012) Assessments of genetic diversity in country bean (Lablab purpureus L.) using RAPD marker against photo-insensitivity. J Plant Develop 19:65-71

Saravanan S, Shanmugasundaram P, Senthil N, Veerabadhiram P (2013) Comparison of genetic relatedness among Lablab bean (Lablab purpureus L. sweet) genotypes using DNA markers. Int J Integr Biol 14(1):23

Saruchi S, Thakur D (2014) Biochemical basis for bruchid resistance in cowpea, chickpea and soybean genotypes. Am J Food Technol 9(6):318-324. https://doi.org/10.3923/ajft. 2014.318.324

Satovic Z, Avila CM, Cruz-Izquierdo S, Díaz-Ruíz R, GarcíaRuíz GM, Palomino C, Gutiérrez MVJBG (2013) A reference consensus genetic map for molecular markers and economically important traits in faba bean (Vicia fabaL.). BMC Gen 14(1):1-15. https://doi.org/10.1186/1471-216414-932

Satyagopal K, Sushil S, Jeyakumar P, Shankar G, Sharma O, Boina D, Ram A (2014) AESA based IPM package for Redgram. Retrieved from Hyderabad:

Saxena RK, Varma Penmetsa R, Upadhyaya HD, Kumar A, Carrasquilla-Garcia N, Schlueter JA, May GD (2012) Large-scale development of cost-effective single-nucleotide polymorphism marker assays for genetic mapping in pigeonpea and comparative mapping in legumes. DNA Res 19(6):449-461. https://doi.org/10.1093/dnares/dss025

Seram D, Mohan S, Kennedy J, and Senthil N (2016) Development and damage assessment of the storage beetle, Callosobruchus maculatus (Thanjavur and Coimbatore strain) under normal and controlled conditions. In: Proc. 10th Int. Conf. on Controlled Atmosphere and Fumigation in Stored Products (CAF), Held in Winnipeg, Canada., pp 25-31

Sharma R, Devi R, Yadav S, Sharma R, Sharma U, Kumar A, Godara P (2016) Effect of some botanicals against pulse beetle, Callosobruchus maculatus (F.) infesting pigeonpea. Legume Res Int J 39(6):1043-1047

Sharma H, Jaba J, and Vashisth S (2017) Distinguishing proof and utilization of resistance of insect pests in grain legumes: progress and limitations. In Breeding Insect Resistant Crops for Sustainable Agriculture. Springer, Berlin, pp 131-170

Shibli M, Rasul MG, Islam A, Saikat M, Haque MM (2021) Genetic diversity of country bean (Lablab purpureus) genotypes collected from the coastal regions of Bangladesh. J Horticul Postharvest Res 4(2):93-104

Shivachi A, Kiplagat K, Kinyua GJRJ (2012) Microsatellite analysis of selected lablab purpureus genotypes in Kenya. Rwanda J 28(1):39-52. https://doi.org/10.4314/rj.v28i0.3

Shivakumar M, Ramesh S (2015) Transferability of cross legume species/genera SSR markers to dolichos bean (Lablab purpureus L. Sweet) var. Lignosus. Ecialise Sp 49(2):263-265
Singh A, Abhilash P (2019) Varietal dataset of nutritionally important Lablab purpureus (L.) sweet from Eastern Uttar Pradesh, India. Data Brief 24:103935

Singh V, Kudesia R, and Bhadauria S (2019) Assessment of genetic diversity in some Indian Lablab purpureus, L. Bean genotypes based on RAPD marker. Proceedings of the National Academy of Sciences, India Section B: Biological Sciences, 1-7 https://doi.org/10.1007/s40011-01901158-X

Sitienei RC, Onwonga RN, Lelei JJ, Kamoni P (2017) Use of Dolichos (Lablab Purpureus L.) and combined fertilizers enhance soil nutrient availability, and maize (Zea Mays L.) yield in farming systems of Kabete Sub County Kenya. Agric Sci Res J 7(2):47-62

Smith CM (2005) Plant resistance to arthropods: Molecular and Conventional Approaches. Springer, Berlin, Germany

Somta P, Talekar N, Srinives P (2006) Characterization of Callosobruchus chinensis (L.) resistance in Vigna umbellata (Thunb.) Ohwi \& Ohashi. J Stored Prod Res 42(3):313-327. https://doi.org/10.1016/j.jspr.2005.05.003

Somta P, Ammaranan C, Ooi P, Srinives P (2007) Inheritance of seed resistance to bruchids in cultivated mungbean (Vigna radiata, L. Wilczek). Euphytica 155:47-55. https://doi.org/ 10.1007/s10681-006-9299-9

Somta P, Kaga A, Tomooka N, Isemura T, Vaughan DA, Srinives P (2008) Mapping of quantitative trait loci for a new source of resistance to bruchids in the wild species Vigna nepalensis Tateishi \& Maxted (Vigna subgenus Ceratotropis). Theor Appl Genet 117(4):621-628. https://doi. org/10.1007/s00122-008-0806-3

Southgate B (1979) Biology of the Bruchidae. Annu Rev Entomol 24(1):449-473. https://doi.org/10.1146/annurev. en.24.010179.002313

Srinivasan R (2014) Insect and mite pests on vegetable legumes: a field guide for identification and management. Shanhua, Taiwan.: AVRDC-The World Vegetable Center.

Sserumaga JP, Kayondo SI, Kigozi A, Kiggundu M, Namazzi C, Walusimbi K, Evolution C (2021) Genome-wide diversity and structure variation among lablab [Lablab purpureus (L.) Sweet] accessions and their implication in a Forage breeding program. 1-14

Stout MJ (2014) Host-plant resistance in pest management. In Integrated Pest Management. Elsevier, Amsterdam pp 1-21

Subekti N, Nur H, Fanidya A, Susanti S, Saputri R, and Indrawati P (2019) Chlorpyrifos organophosphate and essential oils activities against Callosobruchus maculatus (F.) warehouse pests. In: Journal of Physics: Conference Series, Held in, pp 1-4

Sulaiman A, Lawal MA, Sciences A (2018) A proximate, mineral composition and anti-nutritional factors of the aerial parts of Lablab purpureus (L.) sweet. Bayero J Pure Appl Sci 11(1):37-40

Thottathil GP, Jayasekaran K, Othman AS (2016) Sequencing crop genomes: a gateway to improve tropical agriculture. Tropical Life Sci Res 27(1):93

Tigist SG, Melis R, Sibiya J, Keneni G (2018) Evaluation of different Ethiopian common bean, Phaseolus vulgaris 
(Fabaceae) genotypes for host resistance to the Mexican bean weevil, Zabrotes subfasciatus (Coleoptera: Bruchidae). Int J Trop Insect Sci 38(1):1-15. https://doi.org/10. 1017/s1742758417000248

Togola A, Boukar O, Belko N, Chamarthi S, Fatokun C, Tamo M, Oigiangbe N (2017) Host plant resistance to insect pests of cowpea (Vigna unguiculata L. Walp): achievements and future prospects. Euphytica 213(11):1-16

Tolera T, Karlovsky P, and Maass BL (2008) Genetic diversity in tropical legumes: cowpea (Vigna unguiculata (L.) Walp.) and lablab (Lablab purpureus (L.) Sweet). In: Proceedings of 14th Agronomy Conference, Held in Adelaide, South Australia. 21-25 pp 1-6

Tolera $\mathrm{T}$ (2006) Towards improved vegetable use and conservation of cowpea and lablab: agronomic and participatory evaluation in northeastern Tanzania and genetic diversity study. (Ph. D), University of Göttingen, Germany

Tripathy SK (2016) Bruchid resistance in food legumes-an overview. Res J Biotechnol 11:97-105

Kirkhouse Trust (2019) Supporting research and education in biological sciences: Agricultural crop improvement for the relief of poverty, with a focus on legumes. Retrieved September 10, 2019, from Stress Tolerant Orphas Legumes (STOL) Project at NM-IAST, Arusha -Tanzania website: https://www.kirkhousetrust.org/stolprojects

Vaijayanthi P, Ramesh S, Gowda MB, Rao AM, Keerthi C (2015) Development of core sets of Dolichos bean (Lablab purpureus L. Sweet) germplasm. J Crop Improve 29(4):405-419. https://doi.org/10.1080/19315260.2014. 883459

Vaijayanthi P, Ramesh S, Gowda M, Rao A, Keerthi C (2019) Genome-wide marker-trait association analysis in a core set of Dolichos bean germplasm. Plant Genetic Resources 17(1):1-11. https://doi.org/10.1017/s1479262118000163

van Hintum TJ, Brown A, and Spillane C (2000) Core collections of plant genetic resources. Retrieved from Rome:

Van Huis A (1991) Biological methods of bruchid control in the tropics: a review. Int J Trop Insect Sci 12(1-3):87-102. https://doi.org/10.1017/s1742758400020579

Vanitha K, Saidaiah P, Sudini H, Geetha A, Reddy KR (2018) Oxygen requirement of dolichos bean bruchids at different stages of its life cycle. J Pharmacogn Phytochem 7(5):2183-2185

Venkatesha S, Gowda MB, Mahadevu P, Rao AM, Kim D, Ellis T, Knox M (2007) Genetic diversity within Lablab purpureus and the application of gene-specific markers from a range of legume species. Plant Gen Resour 5(3):154. https://doi.org/10.1017/s1479262107835659

Wallace TC, Murray R, Zelman KM (2016) The nutritional value and health benefits of chickpeas and hummus. Nutrients 8(12):766

Wang M, Morris J, Barkley N, Dean R, Jenkins T, Pederson G (2007a) Evaluation of genetic diversity of the USDA Lablab purpureus germplasm collection using simple sequence repeat markers. J Hortic Sci Biotechnol 82(4):571-578. https://doi.org/10.1080/14620316.2007. 11512275

War AR, Paulraj MG, Ahmad T, Buhroo AA, Hussain B, Ignacimuthu S, Sharma HC (2012) Mechanisms of plant defense against insect herbivores. Plant Signal Behav 7(10):1306-1320. https://doi.org/10.4161/psb.21663
War AR, Paulraj MG, Hussain B, Buhroo AA, Ignacimuthu S, Sharma HC (2013) Effect of plant secondary metabolites on legume pod borer, Helicoverpa armigera. J Pest Sci 86(3):399-408

War AR, Murugesan S, Boddepalli VN, Srinivasan R, Nair RM (2017) Mechanism of Resistance in Mungbean [Vigna radiata (L.) R. Wilczek var. radiata] to bruchids, Callosobruchus spp. (Coleoptera: Bruchidae). Front Plant Sci 8:1031. https://doi.org/10.3389/fpls.2017.01031

Washaya S, Mupangwa J, Muchenje V (2018) Chemical composition of Lablab purpureus and Vigna unguiculata and their subsequent effects on methane production in Xhosa lop-eared goats. South African J Animal Sci 48(3):445-458. https://doi.org/10.4314/sajas.v48i3.5

Watson A, Ghosh S, Williams MJ, Cuddy WS, Simmonds J, Rey MD, Hickey LT (2018) Speed breeding is a powerful tool to accelerate crop research and breeding. Nat Plants 4(1):23-29. https://doi.org/10.1038/s41477-017-0083-8

Weldekidan MB (2019) Genetics of cowpea resistance to bruchid (Callosobruchus maculatus Fab.). (Ph. D Dissertation), Makerere University, Uganda

Whitbread A, Ayisi K, Mabapa P, Odhiambo JJ, Maluleke N, Pengelly B (2011) Evaluating Lablab purpureus (L.) Sweet germplasm to identify short-season accessions suitable for crop and livestock farming systems in southern Africa. Afr J Range Forage Sci 28(1):21-28. https://doi.org/10.2989/ 10220119.2011.570950

Xu Y, Li P, Zou C, Lu Y, Xie C, Zhang X, Olsen MS (2017) Enhancing genetic gain in the era of molecular breeding. J Exp Bot 68(11):2641-2666. https://doi.org/10.1093/jxb/ erx135

Yang W, Feng H, Zhang X, Zhang J, Doonan JH, Batchelor WD, Yan J (2020) Crop phenomics and high-throughput phenotyping: past decades, current challenges, and future perspectives. Mol Plant 13(2):187-214. https://doi.org/10. 1016/j.molp.2020.01.008

Yao L, Zhang L, Hu Y, Wang B, and Wu TJIJOG (2012) Characterization of novel soybean derived simple sequence repeat markers and their transferability in hyacinth bean [Lablab purpureus (L.) Sweet]. Indian Journal of Genetics and Plant Breeding, 72(1):46

Ye C, Yu Z, Kong F, Wu S, Wang B (2005) R-ISSR as a new tool for genomic fingerprinting, mapping, and gene tagging. Plant Mol Biol Report 23(2):167-177. https://doi. org/10.1007/bf02772707

Yssel AE, Kao S-M, Van de Peer Y, Sterck L (2019) ORCAEAOCC: A centralized portal for the annotation of african orphan crop genomes. Genes 10(12):950. https://doi.org/ $10.3390 /$ genes 10120950

Yuan J, Wang B, Wu T (2011) Quantitative trait loci (QTL) mapping for inflorescence length traits in Lablab purpureus (L.) sweet. Afr J Biotechnol 10(18):3558-3566. https://doi.org/10.5897/AJB10.536

Yusuf AU, Dike MC, Adebitan SA, Ahmed BI (2011) Comparative efficacy of seven plant products on the cowpeaburchid, callosobruchus maculatus F. development and damage. J Biopest 4:19-26

Zhang G, Xu S, Mao W, Gong Y, Hu Q (2013) Development of EST-SSR markers to study genetic diversity in hyacinth bean (Lablab purpureus L.). Plant Omics 6(4):295-301 
Zietkiewicz E, Rafalski A, Labuda D (1994) Genome fingerprinting by simple sequence repeat (SSR)-anchored polymerase chain reaction amplification. Genomics 20(2):176-183. https://doi.org/10.1006/geno.1994.1151
Publisher's Note Springer Nature remains neutral with regard to jurisdictional claims in published maps and institutional affiliations. 